\title{
Proselytising the Regulation of Religious Bodies \\ in South Africa: Suppressing Religious Freedom?
}

R Henrico*

\section{P.E.R}

Pioneer in peer-reviewed, open access online law publications

Author

Radley Henrico

Affiliation

University of the Western Cape South Africa

Email

rhenrico@uwc.ac.za

Date Submission

9 July 2018

Date Revised

3 February 2019

Date Accepted

4 February 2019

Date published

12 March 2019

Editor Prof O Fuo

How to cite this article

Henrico R "Proselytising the

Regulation of Religious Bodies in South Africa: Suppressing

Religious Freedom?" PER / PELJ 2019(22) - DOI

http://dx.doi.org/10.17159/1727-

3781/2019/v22i0a5315

Copyright

DOI

http://dx.doi.org/10.17159/1727-

3781/2019/v22i0a5315

\begin{abstract}
In democratic pluralistic and secular societies, freedom of religion is a fundamental right to be enjoyed by all individuals and religious organisations. A unique feature of this human right is the extent to which it is premised on a personal belief. The latter can be "bizarre, illogical or irrational", but nevertheless deserving of protection in the interests of freedom of religion. However, when the expression of a religious belief or practice transgresses the civil or criminal law it must be dealt with in the relevant legislative framework to hold the transgressor liable. Measures taken by the state to regulate religious bodies in terms of a general supervisory council or umbrella body are an unreasonable and unjustifiable interference with freedom of religion, and hence unconstitutional. I am of the view that the right to freedom of religion depends for its constitutional validity - and viability - on there being no interference (or regulation) by the state except in instances as provided for in terms of relevant legislation.
\end{abstract}

\section{Keywords}

Secular; freedom of religion; belief; regulation; legislative framework. 


\section{Introduction}

Writing laws is easy, but governing is difficult. ${ }^{1}$

All democratic societies are characterised by the role of the rule of law in maintaining governance and good order. In many ways this is a modernday and jurisprudential manifestation of the Hobbesian social contract to which we have undertaken to hold ourselves bound in exchange for protection by the state. ${ }^{2}$ However, whilst we enjoy the protection of the state, we abhor its undue interference in our freedoms. Implicit in law is a set of norms regulating all forms of conduct in our society. Freedom of religion is guaranteed under the Constitution of the Republic of South Africa, $1996^{3}$ (the Constitution). It is to be enjoyed by individuals ${ }^{4}$ and religious associations ${ }^{5}$ or persons belonging to a religious community for the purpose of practising their religion. ${ }^{6}$ Recently, the Commission for the Promotion and Protection of the Rights of Cultural, Religious and Linguistic Communities (the CRL Rights Commission) made representations to Parliament for legislation to be passed seeking to regulate and control religious bodies ${ }^{7}$ in South Africa. These representations have been received with mixed responses. The purpose of this article is firstly to examine the feasibility of some of the proposed regulations. Secondly, and more significantly, these envisaged regulations should be assessed against the impact they are likely to have on religious freedom in South Africa. In section 3 this article looks at the significance of religious freedom in a democracy. Section 4 examines the proposals put forward by the CRL Rights Commission, discounting them as essentially ineffective and unfeasible. Section 5 discusses the reasons why state regulation of religious freedom should not be permitted. Section 6 contains concluding observations which contend that any system of state

Radley Henrico. BProc LLB (WITS) LLM (cum laude) (UJ) LLD (NWU). Senior Lecturer, Faculty of Law, University of the Western Cape, South Africa. E-mail: rhenrico@uwc.ac.za

Tolstoy War and Peace 200.

See Milonakis and Fine From Political Economy to Economics 11; Glendon 2004 Northwestern Journal of Human Rights 1-11.

3 Section 15(1) of the Constitution of the Republic of South Africa, 1996 provides that everyone has the right to freedom of conscience, religion, thought, belief and opinion.

$4 \quad$ Section 15(1) of the Constitution.

5 Section 31(1) of the Constitution. The term "association" is used in this paper in the broadest sense of referring to religion-based groups, such as churches, religious communities, and organisations which have as their purpose to bring individuals together to share in and participate in the practice of a collective religious ideology, faith or belief.

$6 \quad$ Section 31(1) of the Constitution.

7 The term "bodies" is used, for the purpose of this paper, interchangeably with reference to religious associations as referred to in fn 5 above. 
regulation of religious freedom is anathema to the ethos of constitutionalism in South Africa.

\section{A vignette of religious freedom in South Africa}

For the most part, South Africa has always been a society in which many religious faiths have been permitted to express their beliefs freely. This phenomenon predates the constitutional dispensation. During apartheid certain church bodies were associated with the ruling minority class. In fact, such church establishments went so far as to place their spiritual endorsement on the race segregation policy of the legislature. In this sense, they were arguably more than complicit in apartheid laws; they endorsed racial segregation as divine law. However, it is not the author's contention that the unbecoming religious practices - considered later in this article stemmed from a racial past or even derived from the policy of apartheid in South Africa. Sunday Observance laws, for example, were applicable to all inhabitants of South Africa. ${ }^{8}$ The point, as borne out in this article, of exploiting individuals on the basis of their religious beliefs, and trying to regulate organisations promoting such beliefs is not a racial issue and cannot be said to be the product of apartheid. Significantly, during the apartheid legal order there was nothing that directly prevented religious bodies ${ }^{9}$ from exercising their religious beliefs in a particular manner subject, however, to the dictates of the apartheid regime. ${ }^{10}$

The coming into operation of the constitutional dispensation in South Africa saw no concomitant increased notional practical sense of religious freedom. By and large, the various religious faiths in South Africa simply continued pursuing their spiritual goals. Even those churches which had formerly been used as spiritual vanguards of the ruling minority party were permitted to continue unhindered in the expression of their religious beliefs - albeit with non-partisan motives. It would be hyperbolic to describe the South Africa since the advent of democracy as deeply religious. However, with a population of 55,7 million, ${ }^{11}$ the fact remains that South African society is a vastly pluralistic society emblematic of a diversity of cultures. This fact also informs the sundry religions we find in South Africa. ${ }^{12}$ It could, perhaps be

$8 \quad$ See Van der Vyver 2000 Emory Int'l L Rev 779-781.

9 The term refers loosely to churches, religious faiths, and organisations of faith-based communities.

10 An example would be that the Group Areas Act 41 of 1950 would prevent a church from building a church hall to be used by non-white members of the church in a geographical area zoned for the white minority population of the country.

11 Stats SA $2016 \quad$ http://www.statssa.gov.za/publications/publications/ P0318/P03182016.pdf.

12 According to the 2015 General Household Survey, religious affiliations per province are grouped under what appears to be a finite nomenclature, namely Christian; Muslim; Ancestral tribal, Animist or other African Traditional Religions (ATR); Hindu; 
described as a society in which religious freedom is celebrated in a comingling, pluralistic society. ${ }^{13}$ The significance for all religions ${ }^{14}$ in this society is that they can all claim constitutional protection for their faiths, which can be accommodated under the constitutional precept of freedom of religion. ${ }^{15}$

Generally speaking, it would not be entirely accurate to refer to South Africa as a secular state. ${ }^{16}$ The term "religiously neutral state" would be more appropriate. ${ }^{17}$ Whilst no official or formal state policy in terms of which religion is enforced on the citizens or members of the country exists, ${ }^{18}$ allowance is made for the state to participate in and sponsor religions, but only on a basis of the equal treatment of religions. ${ }^{19}$ Religious freedom in South Africa is not controlled by a supervisory body and neither is our

Jewish; Other religion; Nothing in particular; and Do not know (Stats SA 2015 https://www.statssa.gov.za/publications/P0318/P03182015.pdf 30). But this table must be read in the context that each recognised religion has the potential to embrace other forms and types of religions. "Other traditional African religions" can constitute any amount or sum of religions or affiliations. By the same token the Hindu faith can include mainline Buddhism but does not necessarily exclude Sikhism and Jainism. Alternatively, to what extent should or could Confucianism or Taoism also be considered a religion under the umbrella term of "Other religion"? For further reading see Marshall 2013 IJRF 8-10. Where reference to ATR is concerned, the term is used loosely to refer to the wide variety of religious practices in Africa, which range from more formal recognised religions such as Catholicism and Protestantism to the well-known Zion Christian Church - with its headquarters at Zion City of Moria, east of Polokwane - to more traditional forms of worship of a ceremonial nature extending into deeply-held cultural beliefs and traditions. For further reading on ATR see Van der Vyver 2008 AHRLJ 342-343; Hackett "Tradition, African, Religious, Freedom?" 92-95; Mndende 2013 NGTT 74-82; Chimuka 2016 Studie Historiae Ecclesiasticae 129-133.

13 See Benson 2008 CCR 298-299; Farrow Recognising Religion in a Secular Society 83-93; Benson 1999 UBC Law Rev 520-551.

14 At the time of writing this paper only the 2015 General Household Survey Report on religions in South Africa was available. The information from the 2016 survey in this regard does not appear to differ significantly from Stats SA's General Household Survey 2015.

15 Neither the individual right to freedom of religion under s 15(1) nor the associational right thereof under s 31(1) in terms of the respective provisions of the Constitution are absolute. S 31(1) is in itself a limitation clause; however, both ss 15 and 31 are subject to the general limitation clause of the Constitution as expressed in terms of s 36(1)(a)-(f).

16 In terms of the terminology of "worldly" or "non-sacred" as used by Venter Constitutionalism and Religion 20.

17 Van der Vyver and Green 2008 AHRLJ 345.

18 See Leatt 2007 JSR 29-44; Ismail 2001 Ind Int'I \& Comp L Rev 563-586; Cook 2013 Yale J L \& Human 437; Ferrari 2011 IJRF 35. Although South Africa's national anthem contains the words "God bless Africa" and the Preamble to the Constitution refers to "May God protect our people" this has been interpreted by the constitutional court as relevant to "ceremonial deism" as opposed to any particular religious reference in Ex Parte Speaker of the Western Cape Provincial Legislature 19974 SA 795 (CC) as pointed out by Van der Vyver and Green 2008 AHRLJ 345. Van der Vyver and Green 2008 AHRLJ 345. 
society regulated as a theocracy. ${ }^{20}$ Instead it is one in which allowance is made for the pursuit of individual and collective freedoms, subject to the rule of law. ${ }^{21}$ Such rights and freedoms were curtailed under the authoritative regime of apartheid, but the limitation and restriction of rights in this historical context was insufficient to suggest that South Africa was ever ruled in terms of a theocracy. The fact that the Dutch Reformed (NG) Church played a dominant role in endorsing the political policies of the executive ruling minority elite does not suggest that the state imposed a particular form of religion on the population. There is no official "establishment clause" in the South African Constitution ensuring separation between state and religion. However, that this separation does in fact exist is borne out by the reality of the absence of any suggestion of state interference in the affairs of religious freedom. Support for this is found in the National Policy on Religion and Education ${ }^{22}$ (hereafter the Policy), which expressly provides as follows:

Under the constitutional guarantee of freedom of religion, the state neither advancing nor inhibiting religion, must assume a position of fairness, informed by parity of esteem for all religions ... ${ }^{23}$

The US, which is regarded by many as the pinnacle of democracy, liberty and freedom, is also known for being a secular country, ${ }^{24}$ this opinion being attributable to what has been referred to as the "establishment clause". In

20 Such as countries where religion is imposed by the state upon its citizens as a way of life, where in effect an individual is left with no choice but to adhere to the official recognised religion, failing which the result can be persecution as well as prosecution by the state authorities. This is especially the case in Islamic states (known as dawla islamiyya or caliphate states) governed by Sharia law. For further reading in this regard, see Moosa 2001 J L Relig 185; Pew Research Centre 2013 http://www.pewforum.org/2013/04/30/the-worlds-muslims-religion-politics-societyoverview/. According to this source, an overwhelming percentage of Muslims in countries across the world actively seek Islamic law (Sharia) to be the official law of the land which governs their conduct, whilst some subjects argue that the law should apply only to Muslims. Such an Islamic state must also be seen in the context of Islamic fundamentalism and the problems related thereto, such as the Al-Qaeda attack on the World Trade Centre in New York on 11 September 2009; the ongoing dispute over the Brotherhood in Egypt, and the terrorist group Islamic State (IS) in Iraq and Syria. In this regard see Al-Dawoody Islamic Law of War 111. Pope Francis condemned religious fundamentalisms as "deviant forms of religion" following the December 2014 terrorist attacks in Paris and the ongoing strife in the Middle East, according to Moloney 2015 https://www.wsj.com/articles/pope-denounces-deviantforms-of-religion-1421067797. Also see Sedgwick 2015 Perspectives on Terrorism 39; Al-Dawoody 2015 Kansai U Rev L \& Pol 103-104; Stilt 2010 Tex Int'l LJ 76-78. For further reading see Campos 1994 Colum L Rev 1825; Lenta 2005 SALJ 363366.

South African Government 2003 https://www.gov.za/sites/default/files/gcis document/201409/religion0.pdf. South African Government 2003 https://www.gov.za/sites/default/files/gcis_ document/201409/religion0.pdf. In terms of a strict separation between state and religion. 
terms of the US Constitution, "Congress shall make no law respecting an establishment of religion, or prohibiting the free exercise thereof". ${ }^{25} \mathrm{In}$ Everson $v$ Board of Education ${ }^{26}$ Justice Black stated:

Neither a state nor the Federal Government can set up a church. Neither can pass laws which aid one religion, or prefer one religion over another...

Effectively, what emerges from this model is a situation in which there is no relation between the state or government and any religious affiliation and/or the practice thereof. Rawls ${ }^{27}$ advocates that this form of government is to be encouraged, since the state refuses to use any particular form of religious ideology which it imposes on its citizens. Religion and the freedom to practice one's beliefs are matters left to the conscience and personal subjective belief of each and every person. This is not a realm into which the government (state) intends venturing. For reasons advanced in section 4 of this article, interference with the right to religious freedom is best left to the adjudicative interpretation and discretion of our courts.

Canada serves as an example of another country which is extremely diverse in terms of its population make-up and yet secular in terms of its relation between state and religion. ${ }^{28}$ The significance of the Canadian framework is the degree to which it has expressed the urgency of and need for an inclusive all-embracing approach to accommodating diverse views in a pluralistic society. In this sense Canada is said to be inclusively secular. ${ }^{29}$ The diversity of views celebrated in a pluralistic society which has been recognised in Benson refers to the Canadian Appeal court decision in Chamberlain $v$ Surrey School Board, ${ }^{30}$ in which Gonthier J states the following:

... nothing in the Charter, political or democratic theory, or a proper understanding of pluralism demands that atheistically based moral positions trump religiously based moral positions on matters of public policy ... The key is that people will disagree about important issues, and such disagreement, where it does not imperil community living, must be capable of being accommodated at the core of a modern pluralism. ${ }^{31}$

\footnotetext{
25 US Constitution (First Amendment).

$26 \quad$ Everson $v$ Board of Education 330 US 1 (1947) 15.

27 See Rawls Political Liberalism 29-33.

28 See Berman, Bhargava and Laliberté Secular States and Religious Diversity 103; Van Praagh 2001 Can Bar Rev 605; Moon Law and Religious Pluralism 2; Roald 2011 https://www.cmi.no/publications/file/4239.pdf 152-153; Benson 2007 Emory Int'l L Rev 111-165; Benson 2010 JSR 17-41; Berger 2002 Can J L \& Soc'y 39-68.

29 Benson 2008 CCR 295-313.

$30 \quad$ Chamberlain v Surrey School Board 200080 BCLR (3d) 181 (CA).

$31 \quad$ Chamberlain v Surrey School Board 200080 BCLR (3d) 181 (CA) para 137.
} 
The brief reference to the US and Canada contextualises the approach adopted by our constitutional court regarding religious freedom. In Minister of Home Affairs v Fourie, ${ }^{32}$ Sachs J observed:

In the open and democratic society contemplated by the Constitution there
must be mutually respectful co-existence between the secular and the sacred.
The function of the Court is to recognise the sphere which each inhabits, not
to force the one into the sphere of the other... The hallmark of an open and
democratic society is its capacity to accommodate and manage difference of
intensely-held world views and lifestyles in a reasonable and fair manner...

Significant similarities may be drawn between such liberal democracies like Canada and the US and a fledgling democracy like South Africa in relation to the guarantee of religious freedom; namely, that it is a freedom in respect of which the state must desist from interfering. Alternatively, where it does play some role it must at the very least ensure that it accords equal recognition to all religions and does not favour one above another.

In the next part of this paper I will discuss how the CRL Rights Commission purports to persuade parliament to regulate religious freedom in South Africa. Why such proposals are for the most part lacking in cogency and rationality appears from the discussion.

\section{The CRL Rights Commission and its proposals to parliament}

The CRL Rights Commission is a state institution established in terms of Chapter 9 of the Constitution to support democracy. ${ }^{34}$ Its function is to investigate, advise and report on religious rights issues. ${ }^{35}$ It is a juristic, independent statutory body regulated by the Commission for the Promotion and Protection of the Rights of Cultural, Religious and Linguistic Communities Act (the CRL Rights Commission Act), ${ }^{36}$ from which it essentially derives its statutory wherewithal to fulfil its constitutional

$32 \quad$ Minister of Home Affairs v Fourie 20061 SA 524 (CC).

33 Minister of Home Affairs v Fourie 20061 SA 524 (CC) paras 94-98.

34 Established under s 181(1)(c) of the Constitution.

35 Section 185(2), as read with subsections (1) and (3) of the Constitution. The CRL Rights Commission's mandate includes the rights of cultural and linguistic communities; but for the purposes of this paper only religious communities (bodies) are considered.

36 Commission for the Promotion and Protection of the Rights of Cultural, Religious and Linguistic Communities Act 19 of 2002, especially s 3(a)-(b). The powers given to the CRL Rights Commission under the CRL Rights Commission Act include, but are not limited to, bringing any relevant matter (such as an infraction of the criminal or civil law) to the attention of the authority or organ of state, and making recommendations in respect of such a matter; see $s 5(1)(k)$. 
functions. ${ }^{37}$ As its name implies, it is a state organisation, and hence an arm of the national executive. There is no denying the fact that the CRL Rights Commission is an organ of state as this term is defined under section 239 of the Constitution. The significance of this is discussed in greater detail below. Whilst a Chapter 9 state institution may be lauded for researching and investigating a particular issue, the extent to which its recommendations purport to regulate religious freedom is entirely another matter. Put differently, where such recommendation(s) constitute the basis of notional or even conceptual state regulation of a religious freedom, they should be regarded with circumspection for reasons advanced in Part 5 of this article. Firstly, it is important to look at what gave impetus to the CRL Rights Commission and its proposals to parliament. Secondly, the nature of the proposals will be considered.

During the course of 2016, sporadic incidents occurred in South Africa where certain church congregations fell prey to malevolent practices on the part of their pastors or ministers. One such incident involved a self-styled proclaimed prophet at the Mount Zion General Assembly Church, commonly known as the "prophet of doom", who sprayed an insecticide with the brand name Doom ${ }^{38}$ in the faces and on the bodies of congregants during church services for purported healing purposes. ${ }^{39}$ In 2015 headlines were made by a pastor who made congregants eat snakes, drink petroleum and remove their clothing as part of their religious worship. ${ }^{40} \mathrm{~A}$ year earlier congregants of another religious body had been ordered by their pastor to eat grass as a means of bringing them closer to God. ${ }^{41}$

The widespread media coverage of such events culminated in the CRL Rights Commission issuing a Report of the Hearings on Commercialisation of Religion and Abuse of People's Belief Systems (the Report). Prior to the issuance of the Report, the CRL Rights Commission conducted certain investigative studies with the aims, inter alia, of procuring a "societal" understanding pertaining to individuals falling victim (and becoming gullible)

37 Other Chapter 9 state institutions supporting democracy, with the aim of strengthening the constitutional democratic precept of the Republic, include the Public Protector; the South African Human Rights Commission; the Commission for Gender Equality; the Auditor-General and the Electoral Commission. See ss 181(1)(a)-(f), as read with subsections (2)-(5) of the Constitution. The offender, Lethebo Rabalago, was subsequently criminally charged for contravening agricultural legislation and causing grievous bodily harm and sentenced to imprisonment or paying a fine in respect thereof. See Motau 2018 http://ewn.co.za/2018/02/09/he-s-doomed-prophet-of-doom-found-guilty. Reilly 2014 http://www.dailymail.co.uk/news/article-2537053/Lawn-ChristiansSouth-African-preacher-makes-congregation-eat-GRASS-closer-God.html.

40 Nemakonde 2015 https://citizen.co.za/news/south-africa/423976/pastor-mngunimakes-congregation-eat-snakes/.

41 Reilly 2014 http://www.dailymail.co.uk/news/article-2537053/Lawn-ChristiansSouth-African-preacher-makes-congregation-eat-GRASS-closer-God.html. 
to practices as outlined above; of identifying causes relating to the commercialisation of religion and traditional healing; 42 of investigating "miraculous claims [made by certain] religious leaders; [of realising] the legal framework [regulating] the religious and traditional sectors; and [of formulating] findings and recommendations that address the status quo on commercialisation of religion and traditional healing". ${ }^{43}$

The Report's findings are based on data derived from the random sampling of religious bodies and hearings that took place over the nine provinces of South Africa over a period of merely four months. ${ }^{44}$ Some eighty-five religious leaders representing various religions in South Africa were called to "face-to face" interviews with the CRL Rights Commission. ${ }^{45}$ The recommendations of the $\mathrm{CRL}$ Rights Commission ${ }^{46}$ included the establishment of a so-called Peer-Review Committee (the PRC) which is envisaged to be an umbrella organisation representative of particular religions in South Africa. A chosen member for each of the aforesaid religious denominations will form the $\mathrm{PRC}$, which will act as a self-regulatory body aimed at ensuring, inter alia, accountability and the mediation of disputes arising from religious associations or organisations. ${ }^{47}$ The Report expressly attempts to dispel any concerns ${ }^{48}$ about state control or regulation of the constitutionally-enshrined freedom of religion. ${ }^{49}$ The CRL Rights Commission also recommends that the current CRL Rights Commission Act be amended so that the CRL Rights Commission has more powers to intervene in cases where there has been abuse, ${ }^{50}$ and specifically that the $\mathrm{CRL}$ Rights Commission be given the necessary power (through

$42 \quad$ This was in response to complaints that members of the public were falling victim to church ministers using their religious doctrines and teachings to demand that donations be made in the form of tithing or offerings as an atonement for their sins.

43 CRL Rights Commission 2017 http://www.crlcommission.org.za/docs/ Report\%200n\%20Commecialization\%20of\%20Religion\%20and\%20Abuse\%20of \%20People's\%20Believe\%20Systems\%20final.pdf (the Report) 6.

$44 \quad 03$ November 2015 to 23 March 2016. The Report 10.

45 The Report 13. Some of the religious organisations included Freedom of Religion South Africa (FOR SA); the South African Council for the Protection and Promotion of Religious Rights and Freedoms; the Nederduitse Gereformeerde Kerk; the Lutheran Church of South Africa; the Seventh Day Adventists, and Incredible Happenings Ministries. Eighteen of the religious organisations made written submissions. See PMG 2017 https://pmg.org.za/page/CRL\%20Rights? via=homepage-feature-card 42. Since the content of the Interim CRL Commission Report by and large was adopted in the CRL Rights Commission Final Report (referred to in this paper as "the Report") it is not necessary to go into any further detail of the Interim CRL Rights Commission Report.

$46 \quad$ Which were tabled for review before the Parliamentary Committee

$47 \quad$ The Report 47.

48 In terms of representations, submissions and objections.

49 The Report 27-28, 30, 34 and 38.

50 This could, for example, refer to instances where a pastor infringes a fundamental human right of a worshipper. 
amendments to the $C R L$ Rights Commission Act) to ensure that religious bodies "get their [houses] in order". ${ }^{11}$ In ensuring that this is the case, the Commission will be the juristic body that will remain the final arbiter in all matters falling under the purview of the $\mathrm{PRC}^{52}$ and thereby "ensure that freedom of religion is guaranteed in the country and that the religious sector is given space and capacity to resolve its challenges and make all recommendations to [the CRL Rights Commission]". ${ }^{53}$ This is a significant feature of the Report, the importance of which is again suggested in Part 5 of this article.

The merit (or rather, lack thereof) of the Report must certainly depend on certain procedural aspects. In this regard, the Report can roundly be criticised for adopting a "random sampling" methodology in circumstances where it took account of the views of a mere twenty-eight religious institutions and interviewed only eighty-five religious leaders, thus giving inadequate weight to the fact that 94,8 per cent of the South African population is affiliated in some or other way to a religion. ${ }^{54}$ It was also noted by the participants (the religious leaders) who had been summoned to attend the CRL Rights Commission's hearings (held before the Report was compiled) that no mention had been made of any intention by the CRL Rights Commission to propose statutory amendments in relation to the regulation of religion in South Africa. ${ }^{55}$

The point of contention, for the purposes of this article, is the substantive issues which the Report raises. These were diverse and varied. They ranged from concerns that church members were being subjected to (religious) rituals and practices that were unethical or impacted negatively on their human rights; to the abuse of media privileges (by spiritual leaders), such as the use of TV slots to advertise themselves, their faith or holy products; to the deification and hero-worship of church leaders by church members; to subjecting members to fundamentalist thoughts such as refusing to send their children to schools or dissuading them from using banking facilities; to the use of a personal bank account as the religious association's account; and to failing to register as a non-profit organisation and to maintain financial records. ${ }^{56}$ The concept of "commercialisation" played a role, inasmuch as concerns were raised by the CRL Rights Commission in relation to congregants who were asked to make monetary

\footnotetext{
$51 \quad$ The Report 35.

52 The Report 48.

53 The Report 48.

54 Stats SA 2015 https://www.statssa.gov.za/publications/P0318/P03182015.pdf 2729.

55 See FOR SA and SACRRF 2017 http://pmg-assets.s3-website-eu-west1.amazonaws.com/171017SARRF.pdf (the Response).

56 The Report 19-20.
} 
donations to various religious institutions which may not have been registered as non-profit organisations, or the manner in which tithing was collected, namely by means of a hand-held bank-card device. ${ }^{57}$

In response to the aforesaid substantive concerns, Freedom of Religion South Africa (FOR SA) and other interested parties ${ }^{58}$ sought to jettison the $\mathrm{CRL}$ Rights Commission's proposal relating to any legislation that would in any way seek to interfere with freedom of religion by way of regulation. The cogency of their submissions (hereafter referred to as the Response) in this regard was premised on the following:

- religious practices that were potentially harmful, dangerous or unethical had to be dealt with in terms of the existing civil and criminal legislative framework; 59

- instances of "commercialisation" of religion should be understood within the confines of its being nothing out of the ordinary for congregants to offer tithing to religious associations, but that instances of specific alleged irregularities could be reported and investigated by the authorities on a casuistic basis; 60

- $\quad$ to the extent that certain religious associations were said to be flouting advertising laws, not paying tax or not complying with minimum statutory requirements, these were simply cases of individual religious bodies contravening the law. They needed to be referred to the appropriate state institutions for possible prosecution or investigation to cause them to comply; ${ }^{61}$ and

- $\quad$ as opposed to imposing any form of regulation on religious freedom, religious bodies should be afforded the opportunity of availing themselves of a participatory process by all stakeholders with a view to adopting a "Code of Ethics"62 against which religious bodies could

$57 \quad$ The Report 16 and 19.

58 Namely the South African Council for the Protection and Promotion of Religious Rights and Freedoms as well as various denominations (including many of the major churches, denominations and faith groups in South Africa). See the Response.

59 The Response 20-29.

60 The Response 29-30.

61 The Response 30-37.

62 The South African Charter of Religious Rights and Freedoms (the Charter) was a document drafted over several years by a committee of academics, religious leaders, religious scholars, international legal experts and government commissions. It was finally adopted at a public ceremony at the University of Johannesburg on 20 October 2010 in terms of s 234 of the Constitution. The Charter serves to supplement the Bill of Rights in the form of giving recognition to freedom of religion and the rightful place 
ensure a measure of high standards, and where ethics were observed at all times. ${ }^{63}$

Intrinsic to the aforesaid submissions was the abiding concern that the regulation of religion in South Africa, on the basis proposed by the $C R L$ Rights Commission, constituted a violation of the constitutional guarantee to freedom of religion in the country - an anathema to our constitutional dispensation. Some of these concerns are addressed in Part 5 below.

\section{Regulation is not in the interest of religious freedom}

The earliest judicial pronouncement upon the meaning of a religious belief in South African case law dates back more than four decades, when Rumpff CJ in Publication Control Board v Gallo (Africa) Ltd ${ }^{64}$ held that:

Religious beliefs are highly subjective and are founded on faith. [Religion] is not a sphere in which objective concepts of reason are particularly apposite. ${ }^{65}$

This view of religion as a matter of personal reflection in terms of belief was to a large extent prophetic of what the South African Constitutional Court would endorse in Lawrence, Negal, Solberg v State, ${ }^{66}$ wherein Chaskalson $P$ conceded that the court was unable to offer a better definition of freedom of religion than that given in the Canadian authority of $R v$ Big Drug Mart Ltd, ${ }^{67}$ wherein Dickson CJC observed:

The essence of the concept of religion is the right to entertain such religious beliefs as a person chooses, the right to declare religious beliefs openly and without fear of hindrance or reprisal, and the right to manifest belief by worship and practice or by teaching and dissemination. ${ }^{68}$

it is to occupy within the Constitution. Significantly, the Charter could form fertile material for a "Code of Ethics". An emphasis is placed on "future unwarranted state interference with religion". See Malherbe 2011 BYU L Rev 622-623. Article 3, as read with 3.1 of the Charter, refers to the notional absence of state regulation in religious freedom and endorses our "religiously neutral" model of secularism by providing that "[e]very person has the right to impartiality and protection from the state in respect of religion... The state must create a positive and safe environment for the exercise of religious freedom...". Also see SACRRF 2010 https://www.strasbourgconsortium.org/content/blurb/files/South\%20African\%20Cha rter.pdf.

63 The Response 7.

64 Publication Control Board v Gallo (Africa) Ltd 19753 SA 665 (A). Publication Control Board v Gallo (Africa) Ltd 19753 SA 665 (A) 673B-C. Emphasis added.

$66 \quad$ Lawrence, Negal, Solberg v State 19974 SA 1176 (CC).

$67 \quad R v$ Big Drug Mart Ltd 19851 SCR 295.

68 $\quad R v$ Big Drug Mart Ltd 19851 SCR 295 para 92. Emphasis added. 
Later, in Christian Education South Africa v Minister of Education, Sachs J, writing for the minority, referred to the sanctity of freedom of religion in the following vein:

\begin{abstract}
There can be no doubt that the right to freedom of religion, belief, and opinion in an open and democratic society contemplated by the Constitution is important... Yet freedom of religion goes beyond protecting the inviolability of the individual conscience. For many believers their relationship with God or creation is central to all their activities... Religious belief has the capacity to awake concepts of self-worth and human dignity which form the cornerstone of human rights. ${ }^{69}$
\end{abstract}

And in the matter of Prince $v$ President of the Law Society of the Cape of Good Hope ${ }^{70}$ the Constitutional Court once again relied on the aforesaid dictum of Dickson CJC in $R v$ Big M Drug Mart Ltd, ${ }^{71}$ finding that "religion" was to be understood thus:

\begin{abstract}
Religion is a matter of faith and belief. The beliefs that believers hold sacred and thus central to their religious faith may strike non-believers as bizarre, illogical or irrational... The believers should not be put to the proof of their beliefs or faith. For this reason, it is undesirable for courts to enter into the debate whether a particular practice is central to a religion... ${ }^{72}$
\end{abstract}

A cumulative understanding of the above case law is that religion is a deeply-held personal belief. Whilst it is something that can probably be determined objectively, such cases make clear that the belief itself is not required to accord with what the reasonable person (a non-believer) would regard as sensible. Our courts have given their endorsement to an understanding of religion, and by necessary implication, the expression thereof, even where it happens to be "bizarre, illogical or irrational". The latter adjectives do not in and of themselves constitute a danger (or threat) to any other person or their basic human rights, provided of course that such beliefs are not acted out in a manner that does exactly that. The case law also gives impetus to the notion that religion (and its concomitant freedom) is a "moral force"73 to be accommodated in South Africa, a feature of our democracy which can and should not be unduly interfered with by the body politic. More significantly, this endorses the principle that our courts, not the state, must function as the arbiters of determining - albeit in the form of

69 Christian Education South Africa v Minister of Education 20004 SA 757 (CC) para 36. Emphasis added.

70 Prince $v$ President of the Law Society of the Cape of Good Hope 20022 SA 794 (CC).

71 Prince $v$ President of the Law Society of the Cape of Good Hope 20022 SA 794 (CC) para 40.

72 Prince v President of the Law Society of the Cape of Good Hope 20022 SA 794 (CC) per Sachs J para 97. Emphases added. Also see Dlamini v Green Four Security 200611 BLLR 1074 (LC) para 16. Van der Vyver and Green 2008 AHRLJ 344. 
judicial regulation - the extent of religious freedom and the reasonable and justifiable limitations to be imposed upon thereon.

It should be noted that there is absolutely no reason why human rights violations or abuses cannot be dealt with in terms of the existing legislative framework or common law ${ }^{74}$ in South Africa. ${ }^{75}$ The effective prosecution of the "prophet of doom" is testimony to this very fact. The same applies in respect of the other concerns addressed by the CRL Rights Commission, such as non-compliance with statutory requirements. ${ }^{76}$ It is not the contention of the CRL Rights Commission that human rights abuses are a commonplace occurrence in relation to religious bodies. In point of fact, this is mentioned merely once in the CRL Rights Commission's Report. ${ }^{77}$ Moreover, in the Foreword to the Report ${ }^{78}$ reference is made to recent controversial news reports and articles in the media concerning pastors

74 Where individuals are charged in respect of common law offences or conceivably even pursued on civil charges in a civil court.

75 Enforcement of any abuses or violations of rights can be addressed in terms of legislation such as the Schools Act 84 of 1962; the Animals Protection Act 71 of 1962; the Prevention and Combatting of Corrupt Activities Act 12 of 2004; the Prevention of Organised Crime Act 121 of 1998, or under the Code of Advertising Practice of the Advertising Standards Authority of SA. Our law reports are replete with examples of instances where legislative and constitutional rights have been impugned and in which instances our courts have handed down judgments in favour of the prejudiced applicants. In the instance of the prophet of doom case, the Magistrate's court in Polokwane found him guilty on five charges of assault with intent to do grievous bodily harm and of contravening the Agricultural Stock $\begin{array}{llllll}\text { Remedies } & \text { Act } & 36 & \text { of } & 1947 & \text { (Anon } \\ \end{array}$ https://www.news24.com/SouthAfrica/News/day-of-doom-for-pastor-as-court-findshim-guilty-of-assault-20180209). See for example: Afriforum v University of the Free State 20182 SA 185 (CC) in which the court upheld the adoption by the university of a new language policy; EFF $v$ Speaker of the National Assembly 20182 SA 571 (CC) in which the court; made clear what the public protector's remedial action was and that the State President had in fact violated the Constitution (para 108); in Occupiers of Erven 87 \& 88 of Berea v Christiaan Frederick 20175 SA 346 (CC) the court enforced the provisions of $s$ 26(3) of the Constitution preventing the illegal eviction of occupiers of land (property); the North Gauteng High Court in Pretoria (per Prinsloo J) set aside a decision by the Gauteng Department of Education to admit more learners than the number for which the school had capacity (Mitchley 2018 https://www.huffingtonpost.co.za/2018/01/15/afrikaans-medium-school-winscourt-battle-against-education-department_a_23333959); and in Albutt $v$ Centre for the Study of Violence and Reconciliation 20103 SA 293 (CC) the court found that the President is obliged to hear the families of the victims before exercising his prerogative to grant parole to offenders in terms of s $84(2)(\mathrm{J})$ of the Constitution.

76 For example, the non-registration by churches as non-profit organisations in terms of the Non-Profit Organisations Act 71 of 1997 or non-compliance by churches with the Income Tax Act 58 of 1962. Other relevant legislation in this regard would be the Banks Act 94 of 1990; the SA Reserve Bank Act 90 of 1989; the Deeds Registries Act 47 of 1937; the Companies Act 71 of 2008 and the Immigration Act 13 of 2002. The Report 19. The Report 4. 
giving rise to questions whether religion has become a commercial institution.

As previously mentioned, the agitation has more to do with the proposal by the CRL Rights Commission that the religious sector be regulated by means of a peer-review council that will ultimately be overseen by the CRL Rights Commission by means of proposed amendments to the CRL Rights Commission Act. It is envisaged that the Peer-Review Council (the Council) will sit in determination of which church pastor receives a licence to operate a particular religion. Moreover, the powers of the Council (to be established in terms of legislation which must be passed by parliament) will include, but not be limited to, deciding on whether a particular religious leader has a licence to practice and where religious groups may conduct their practices, and acting as a mediator between religious groups and the state. ${ }^{79}$ No details are forthcoming from the CRL Rights commission as to the financial and/or logistic means by which the Council will be established.

In the history of South Africa there has never been a statutory (regulatory) body that has granted religious bodies licences to operate or practice their beliefs. The counter-argument could well be made that what is sought to be achieved is not the regulation of beliefs per se, but of the organisations which promote certain beliefs. For reasons which appear below, it becomes evident that the regulation of any belief by anybody or institution is well-nigh impossible. ${ }^{80}$ As such, it is to the extent that any attempt is made to regulate organisations and religious bodies that a concern looms. The CRL Rights Commission seeks to justify its argument in this regard by relying on a rather tenuous argument that seeks to regulate ${ }^{81}$ religious bodies in accordance with section 22 of the Constitution. ${ }^{82}$ The regulation of trades, professions and certain occupations in accordance with necessary legislative prerequisites is necessary in any democratic society. Adherence to certain basic standards of service delivery and professionalism or even codes of ethics is thus ensured. All of these are objectively determined and readily capable of assessment in terms of whether a member or professional association is compliant. The same cannot be applied to religious institutions on account of the fact that the essence of what they believe (or worship) is not conducive to any stringent definition of what is logical, reasonable or rational. The freedom is spiritual in nature, and save for

79 The Report, for example 34-39.

80 Take for example, the belief which some people have in relation to being vegan or a psychic. The regulation thereof, save to the extent that the expression of such a belief interferes unlawfully with another person, is essentially not capable of being monitored.

81 The Report 39, 41.

82 Which provides that all citizens have the right to choose their trade, occupation or profession freely. 
instances of infractions of the civil or criminal law, there is simply no reason to regulate religious freedom in a free and democratic society. This very aspect of the right in question, namely that it is one which is so vexed with personal beliefs and views, makes it more suitable that in instances where one seeks to limit religious freedom a court, as opposed to a regulatory body, should be the adjudicator. This matter is dealt with in greater detail below.

The creation of the Council (which is to consist of committees for each religion in South Africa) ${ }^{83}$ is extremely far-fetched inasmuch as the $\mathrm{CRL}$ Rights Commission perceives that the Council can be effectively democratically representative of the wide spectrum of religions in South Africa.$^{84}$ A more worrying aspect of the Council is the extent to which it would be deemed as being a regulatory body over religious freedom in South Africa. An even more overarching concern is that of the CRL Rights Commission Act's being amended to give the Commission additional powers to act as the overall supervisory body heading the Council. This, the $\mathrm{CRL}$ Rights Commission contends, will ensure that freedom of religion is guaranteed in South Africa. ${ }^{85}$ However, the means through which this is to be achieved, namely regulation as envisaged, is disproportionate in all the circumstances. This statement is premised simply on the fact that the ultimate recommendation sought by the CRL Rights Commission cannot be viewed as helpful, appropriate, or necessary. ${ }^{86}$ Put differently, the way in which it seeks to address the problems addressed in the Report constitutes an unjustifiable and unreasonable limitation of the right to freedom of religion.

Whilst no right in the Bill of Right is absolute, it is critical to our democratic order that in a pluralistic society that is becoming ever more crowded, with space - not only geographically but notionally and conceptually - becoming narrower, "freedom in all areas of life becomes ever more valuable".87 Numerous commentators have observed that the most basic freedom in a democratic society is religious freedom, and any attempt by the state to regulate this freedom gives rise to disquietude. ${ }^{88}$ The dubious protection afforded freedom of religion (or the lack thereof) in societies like China, Afghanistan or Pakistan is a paradox. Citizens of such countries may have the apparent fundamental rights (which should include freedom of religion) but they are restricted in the manner in which their freedom of religion is

\footnotetext{
$83 \quad$ The Report 45.

$84 \quad$ The Response 52.

85 The Report 38-39

86 See Schlink 2012 Duke J Comp \& Int'l L 293.

87 Schlink 2012 Duke J Comp \& Int'l L 298.

88 See Coertzen 20142014 AHRLJ 140-141; Coertzen 2012 NGTT Supplementum 2 178; Ssenyonjo 2009 ICON 275.
} 
exercised by means either of imposing a particular state-recognised religion or of emphasising state national interests as supreme above individual rights. ${ }^{89}$

It bears mentioning that the Parliamentary Portfolio Committee on Cooperative Governance and Traditional Affairs (COGTA), in considering the Report of the CRL Rights Commission, has been unpersuaded by the proposals either to establish a regulatory Council or to amend the $C R L$ Rights Commission Act. COGTA supports the initiative by religious bodies to engage in further dialogue with a view to adopting a "Code of Ethics" based on the Charter. ${ }^{90}$ The stance adopted by COGTA is encouraging.

As previously stated, the CRL Rights Commission is an organ of state. ${ }^{91}$ Its status as a Chapter 9 constitutional institution does not detract from the fact that it is part of the executive arm of government. Whilst its purpose may be noble and honourable, its status as a state institution cannot (and should not) be ignored. Moreover, the powers of the CRL Rights Commission exercised in terms of the Constitution and the CRL Rights Commission Act are administrative in nature. This means that the exercise of its public powers or the performance of its public functions renders it subject to judicial review. ${ }^{92}$ The $C R L$ Rights Commission repeatedly makes the point that it does not countenance interference by the state in religious freedom. ${ }^{93}$ However, one is presented with the express contradiction appearing from the CRL Rights Commission's proposal that it (the Commission) will issue registration certificates to religious bodies, in consultation with the Council. ${ }^{94}$ On the one hand, the CRL Rights Commission attempts to distance itself from any notional sense of state regulation of religious freedom in South Africa. On the other hand, and to the extent that the CRL Rights Commission advocates its proposals as an organ of state, the conclusion is unavoidable that religion in South Africa, and the extent of its freedom, will ultimately be subject to regulation should its proposals be accepted. Regulation by the Council or the CRL Rights Commission as an umbrella body (both of which will constitute organs of state), essentially constitutes an overreach on the part of the state into the realm of individuals forming the societal and

Venter Constitutionalism and Religion 92-96; Malherbe 2011 BYU L Rev 619 and the authorities cited at fn 39. crls-report-on-regulation-of-religion/. It also falls within the definition of an organ of state as provided for under $\mathrm{s} 1$ of the Promotion of Administrative Justice Act 3 of 2000.

92 See Hoexter Administrative Law 206-210 especially the authority cited at fn 264 .

93 The Report; see for example 27, 30, 34, 39.

94 The Report 39. 
participatory compact of our democratic order who are entitled to exercise their freedom of religion as under sections 15 and 31 of the Constitution.

Infractions of the law, as well as instances of non-compliance which are sought to be enforced through the arm of the law, are matters which fall under the purview of the judicial arm of government as opposed to the executive or legislative arms. This separation of powers, which is essential to the success of our institutional democracy, ensures the fulfilment of two functions. Firstly, our judges, as the independent branch of the government, preside over matters involving disputes which potentially impact upon religious freedom. Due to the nature of the right at issue, our constitutional court has made it clear that such disputes must be adjudicated in a "nuanced and context-sensitive form". ${ }^{95}$ It is inherent in such an approach that the fundamental right to religious freedom is unlikely to be considered in a rough-shod manner but will be treated with the respect it is duly accorded in cases where claims are made for its limitation or restriction. Secondly, placing the determination of disputes about the freedom of religion in the hands of the judiciary, as opposed to "entrusting" religious freedom regulation to an organ of state avoids the inherent anticipatory pitfall of such organ of state having to justify its actions and conduct. It is our judiciary and not the executive or an organ of state which must have the final say ${ }^{96}$ on how religious freedom is to be given content and expression under the Constitution. This is the best guarantee of protecting freedom of religion in our constitutional dispensation.

\section{Conclusion}

The CRL Rights Commission is attempting to persuade parliament to amend the CRL Rights Commission Act in a way that would ultimately permit it to oversee a statutory body which would ultimately act as a selfregulatory council. Religious freedom in South Africa is one of the few rights which has not been blighted with a history of either intervention on the part of the state or restrictions in terms of its expression. Ironically, at a time when South Africa is able to celebrate its Bill of Rights and recently founded constitutional dispensation, attempts are being made by the CRL Rights Commission through its proposals to unduly restrict and limit the country's religious freedom. Whilst not dispelling the concerns raised regarding isolated instances of human rights abuses and other non-compliance with statutory regulations (in terms of practising as a religious association), it

$95 \quad$ Christian Education South Africa v Minister of Education 20004 SA 757 (CC) para 30; Henrico 2012 Obiter 503; Kievits Kroon Country Estate (Pty) Ltd v Mmoledi 2014 35 ILJ 209 (SCA) para 32.

96 See Powell "Law as Justification" $65 \mathrm{ff}$. 
must be understood that all such matters can and should be addressed within the current, existing legislative framework of the country. More importantly, any attempt to restrict or limit religious freedom is a matter which should not be decided by a regulatory body, whether in terms of a self-regulatory scheme or otherwise, on account of the fact that such body ultimately constitutes an organ of state and is part of the executive. Determinations of such disputes are best left to our courts as the independent branch of government. To do so would ensure that the matter was dealt with in terms of the tenets of justice and, more significantly, would guarantee that a court of law, and not the state, sits as the ultimate adjudicator of religious freedom.

\section{Bibliography}

\section{Literature}

Al-Dawoody Islamic Law of War

Al-Dawoody A The Islamic Law of War: Justifications and Regulations (Palgrave MacMillan New York 2011)

Al-Dawoody 2015 Kansai U Rev L \& Pol

Al-Dawoody A "ISIS and its Brutality under Islamic Law" 2015 Kansai U Rev L\& Pol 101-117

Benson 1999 UBC Law Rev

Benson IT "Notes Towards (Re)Defining of the Secular" 1999 UBC Law Rev 520-551

Benson 2007 Emory Int'l L Rev

Benson IT "The Freedom of Conscience and Religion in Canada: Challenges and Opportunities" 2007 Emory Int'l L Rev 111-166

Benson 2008 CCR

Benson IT "The Case for Religious Inclusivism and the Judicial Recognition of Religious Associational Rights: A Response to Lenta" 2008 CCR 295313

Benson 2010 JSR

Benson IT "Taking Pluralism Seriously: The Need to Reunderstand Faith, Beliefs, Religion and Diversity in the Public Sphere" 2010 JSR 17-41

Berger 2002 Can J L \& Soc'y

Berger B "The Limits of Belief: Freedom of Religion, Secularism, and the Liberal State" 2002 Can J L \& Soc'y 39-68 
Berman, Bhargava and Laliberté Secular States and Religious Diversity Berman BJ, Bhargava R and Laliberté A Secular States and Religious Diversity (UBC Press Vancouver 2013)

Campos 1994 Colum L Rev

Campos PF "Secular Fundamentalism" 1994 Colum L Rev 1814-1827

Chimuka 2016 Studie Historiae Ecclesiasticae

Chimuka TA "Afro-pentecostalism and Contested Holiness in Southern Africa" 2016 Studie Historiae Ecclesiasticae 124-141

Coertzen 2012 NGTT Supplementum 2

Coertzen P "Religion and the Common Good in a Pluralistic Society" 2012 NGTT Supplementum 2 175-190

Coertzen 2014 AHRLJ

Coertzen P "Constitution, Charter and Religions in South Africa" 2014 AHRLJ 126-141

Cook 2013 Yale J L \& Human

Cook AE "God Talk in a Secular World" 2013 Yale J L \& Human 435-461

Farrow Recognising Religion in a Secular Society

Farrow D Recognising Religion in a Secular Society: Essays in Pluralism, Religion, and Public Policy (McGill-Queen's University Press Montreal 2004)

Ferrari 2011 IJRF

Ferrari S "Religion and the Development of Civil Society" 2011 IJRF 29-36

Glendon 2004 Northwestern Journal of Human Rights

Glendon MA "The Rule of Law in the Universal Declaration of Human Rights" 2004 Northwestern Journal of Human Rights 1-19

Hackett "Tradition, African, Religious, Freedom?"

Hackett RIJ "Tradition, African, Religious, Freedom?" in Sullivan WF et al (eds) Politics of Religious Freedom (University of Chicago Press Chicago 2015) ch 7

Henrico 2012 Obiter

Henrico R "Mutual Accommodation of Religious Differences in the Workplace: A Jostling of Rights" 2012 Obiter 503-525

Hoexter Administrative Law

Hoexter C Administrative Law in South Africa (Juta Cape Town 2012) 
Ismail 2001 Ind Int'l \& Comp L Rev

Ismail JS "South Africa's Sunday Law: Finding a Compromise" 2001 Ind Int'I \& Comp L Rev 563-586

Leatt 2007 JSR

Leatt A "Faithfully Secular: Secularism and South African Political Life" 2007 JSR 29-44

Lenta 2005 SALJ

Lenta P "Religious Liberty and Cultural Accommodation" 2005 SALJ 352377

Malherbe 2011 BYU L Rev

Malherbe $\mathrm{R}$ "The Background and Contents of the Proposed South African

Charter of Religious Rights and Freedoms" 2011 BYU L Rev 612-636

Marshall 2013 IJRF

Marshall $P$ "Conceptual Issues in Contemporary Religious Freedom Research" 2013 IJRF 7-16

Milonakis and Fine From Political Economy to Economics

Milonakis D and Fine B From Political Economy to Economics: Method, the Social and Historical in the Evolution of Economic Theory (Routledge New York 2009)

Mndende 2013 NGTT

Mndende $\mathrm{N}$ "Law and Religion in South Africa: An African Traditional Perspective" 2013 NGTT 74-82

Moon Law and Religious Pluralism

Moon RJ Law and Religious Pluralism in Canada (University of British Columbia Press Vancouver 2008)

Moosa $2001 \mathrm{~J}$ L Relig

Moosa E "The Dilemma of Islamic Rights Schemes" 2001 J L Relig 185-215

Powell "Law as Justification"

Powell C "Law as Justification: Glenister, Separation of Powers and the Rule of Law" in Andrews P, Davis D and Masengu T (eds) $A$ Warrior of Justice: Essays in Honour of Dikgang Moseneke (Juta Cape Town 2017) $55-74$

Rawls Political Liberalism

Rawls J Political Liberalism (Columbia University Press New York 1993) 
Schlink 2012 Duke J Comp \& Int'I L

Schlink B "Proportionality in Constitutional Law: Why Everywhere but Here?" 2012 Duke J Comp \& Int'l L 291-302

Sedgwick 2015 Perspectives on Terrorism

Sedgwick M "Jihadism, Narrow and Wide: The Dangers of Loose Use of an Important Term" 2015 Perspectives on Terrorism 34-41

Ssenyonjo 2009 ICON

Ssenyonjo M "Limits on the Freedom to Manifest One's Religion in Educational Institutions in Uganda and the United Kingdom" 2009 ICON 275-305

Stilt 2010 Tex Int'l LJ

Stilt K "Islam is the Solution: Constitutional Visions of the Egyptian Muslim Brotherhood" 2010 Tex Int'l LJ 74-104

Tolstoy War and Peace

Tolstoy L War and Peace (Penguin Random House South Africa Randburg 2007)

Van der Vyver 2000 Emory Int'l L Rev

Van der Vyver JD "State-sponsored Proselytization: A South African Experience" 2000 Emory Int'I L Rev 779-848

Van der Vyver and Green 2008 AHRLJ

Van der Vyver JD and Green MC "Law, Religion and Human Rights in Africa: An Introduction" 2008 AHRLJ 337-356

Van Praagh 2001 Can Bar Rev

Van Praagh S "Identity's Importance: Reflections of - and on - Diversity" 2001 Can Bar Rev 604-619

Venter Constitutionalism and Religion

Venter F Constitutionalism and Religion (Edgar Elgar Cheltenham 2015)

Case law

Afriforum v University of the Free State 20182 SA 185 (CC)

Albutt v Centre for the Study of Violence and Reconciliation 20103 SA 293 (CC)

Chamberlain v Surrey School Board 200080 BCLR (3d) 181 (CA) 
Christian Education South Africa v Minister of Education 20004 SA 757 (CC)

Dlamini v Green Four Security 200611 BLLR 1074 (LC)

EFF $v$ Speaker of the National Assembly 20182 SA 571 (CC)

Everson v Board of Education 330 US 1 (1947)

Ex Parte Speaker of the Western Cape Provincial Legislature 19974 SA 795 (CC)

Kievits Kroon Country Estate (Pty) Ltd v Mmoledi 201435 ILJ 209 (SCA)

Lawrence, Negal, Solberg v State 19974 SA 1176 (CC)

Minister of Home Affairs v Fourie 20061 SA 524 (CC)

Occupiers of Erven 87 \& 88 of Berea v Christiaan Frederick 20175 SA 346 (CC)

Prince $v$ President of the Law Society of the Cape of Good Hope 20022 SA 794 (CC)

Publication Control Board v Gallo (Africa) Ltd 19753 SA 665 (A)

R v Big Drug Mart Ltd 19851 SCR 295

\section{Legislation}

Agricultural Stock Remedies Act 36 of 1947

Animals Protection Act 71 of 1962

Banks Act 94 of 1990

Commission for the Promotion and Protection of the Rights of Cultural, Religious and Linguistic Communities Act 19 of 2002

Companies Act 71 of 2008

Constitution of the Republic of South Africa, 1996

Deeds Registries Act 47 of 1937

Group Areas Act 41 of 1950

Immigration Act 13 of 2002 
Income Tax Act 58 of 1962

Non-Profit Organisations Act 71 of 1997

Prevention and Combatting of Corrupt Activities Act 12 of 2004

Prevention of Organised Crime Act 121 of 1998

Promotion of Administrative Justice Act 3 of 2000

SA Reserve Bank Act 90 of 1989

Schools Act 84 of 1962

US Constitution (First Amendment)

\section{Internet sources}

Anon 2018 https://www.news24.com/SouthAfrica/News/day-of-doom-forpastor-as-court-finds-him-guilty-of-assault-20180209

Anon 2018 Day of Doom for Pastor as Court Finds Him Guilty of Assault https://www.news24.com/SouthAfrica/News/day-of-doom-for-pastor-ascourt-finds-him-guilty-of-assault-20180209 accessed 20 March 2018

CRL Rights Commission 2017 http://www.crlcommission.org.za/docs/ Report\%200n\%20Commecialization\%20of\%20Religion\%20and\%20Abus e\%20of\%20People's\%20Believe\%20Systems\%20final.pdf

CRL Rights Commission 2017 Report of the Hearings on the Commercialisation of Religion and Abuse of People's Belief Systems http://www.crlcommission.org.za/docs/Report\%200n\%20Commecializatio n\%20of\%20Religion\%20and\%20Abuse\%20of\%20People's\%20Believe\%2 0Systems\%20final.pdf accessed 20 March 2018

FOR SA 2018 https://forsa.org.za/parliamentary-committee-draftsresponse-to-the-crls-report-on-regulation-of-religion/

Freedom of Religion South Africa 2018 Parliamentary Committee Responds to the CRL's Report on Regulation of Religion https://forsa.org.za/ parliamentary-committee-drafts-response-to-the-crls-report-on-regulationof-religion/ accessed 22 March 2018

FOR SA and SACRRF 2017 http://pmg-assets.s3-website-eu-west1.amazonaws.com/171017SARRF.pdf

Freedom of Religion South Africa and South African Council for the Protection and Promotion of Religious Rights and Freedoms 2017 Comments on the CRL Rights Commission's Report on the 
"Commercialisation" of Religion http://pmg-assets.s3-website-eu-west1.amazonaws.com/171017SARRF.pdf accessed 20 March 2018

Mitchley 2018 https://www.huffingtonpost.co.za/2018/01/15/afrikaansmedium-school-wins-court-battle-against-education-

department_a_23333959

Mitchley A 2018 Afrikaans Medium School Wins Court Battle Against Education Department https://www.huffingtonpost.co.za/2018/01/15/afrikaans-medium-school-wins-court-battle-against-education-department_a_23333959/ accessed 20 March 2018

Moloney 2015 https://www.wsj.com/articles/pope-denounces-deviantforms-of-religion-1421067797

Moloney L 2015 Pope Denounces 'Deviant Forms of Religion' https://www.wsj.com/articles/pope-denounces-deviant-forms-of-religion1421067797 accessed 20 March 2018

Motau 2018 http://ewn.co.za/2018/02/09/he-s-doomed-prophet-of-doomfound-guilty

Motau K 2018 He's Doomed: Lethebo Rabalago Found Guilty http://ewn.co.za/2018/02/09/he-s-doomed-prophet-of-doom-found-guilty accessed 18 March 2018

Nemakonde 2015 https://citizen.co.za/news/south-africa/423976/pastormnguni-makes-congregation-eat-snakes/

Nemakonde V 2015 Pastor Mnguni Makes Congregation Eat Snakes https://citizen.co.za/news/south-africa/423976/pastor-mnguni-makescongregation-eat-snakes/ accessed 20 March 2018

Pew Research Centre 2013 http://www.pewforum.org/2013/04/30/theworlds-muslims-religion-politics-society-overview/

Pew Research Centre 2013 The World's Muslims: Religion, Politics and Society http://www.pewforum.org/2013/04/30/the-worlds-muslims-religionpolitics-society-overview/ accessed 27 February 2016

PMG 2017 https://pmg.org.za/page/CRL\%20Rights?via=homepagefeature-card

Parliamentary Monitoring Group 2017 CRL Rights Commission Report: Commercialisation of Religion and Abuse of People's Belief Systems: Hearings Day 1 https://pmg.org.za/page/CRL\%20Rights?via=homepagefeature-card accessed 20 March 2018

Reilly $2014 \quad$ http://www.dailymail.co.uk/news/article-2537053/LawnChristians-South-African-preacher-makes-congregation-eat-GRASScloser-God.html 
Reilly J 2014 Lawn again Christians: South African Preacher Makes Congregation Eat GRASS to 'Be Closer to God' http://www.dailymail.co.uk/news/article-2537053/Lawn-Christians-SouthAfrican-preacher-makes-congregation-eat-GRASS-closer-God.html accessed 19 March 2018

Roald 2011 https://www.cmi.no/publications/file/4239.pdf

Roald AS 2011 Multiculturalism and Pluralism in Secular Society: Individual or Collective Rights? https://www.cmi.no/publications/file/4239.pdf accessed 20 March 2018

SACRRF 2010 https://www.strasbourgconsortium.org/content/blurb/files/ South\%20African\%20Charter.pdf

South African Council for the Protection and Promotion of Religious Rights and Freedoms 2010 The South African Charter of Religious Rights and Freedoms and the South African Council for the Protection and Promotion of Religious Rights and Freedoms https://www.strasbourgconsortium.org/ content/blurb/files/South\%20African\%20Charter.pdf accessed 22 March 2018

South African Government 2003 https://www.gov.za/sites/default/files/ gcis_document/201409/religion0.pdf

South African Government 2003 National Policy on Religion and Education https://www.gov.za/sites/default/files/gcis_document/201409/religion0.pdf accessed 20 March 2018

Stats SA 2015 https://www.statssa.gov.za/publications/P0318/ P03182015.pdf

Stats SA 2015 General Household Survey https://www.statssa.gov.za/publications/P0318/P03182015.pdf accessed 20 March 2018

Stats SA 2016 http://www.statssa.gov.za/publications/publications /P0318/P03182016.pdf

Stats SA 2016 General Household Survey 2016 http://www.statssa.gov.za/publications/publications/P0318/P03182016.pdf accessed 20 March 2018

\section{List of Abbreviations}

AHRLJ

ATR

BYU L Rev

Can Bar Rev

Can J L \& Soc'y
African Human Rights Law Journal

African Traditional Religions

Brigham Young University Law Review

Canadian Bar Review

Canadian Journal of Law and Society 
CCR

COGTA

Colum L Rev

CRL Rights Commission

Duke J Comp \& Int'l L

Emory Int'I L Rev

FOR SA

ICON

IJRF

Ind Int'I \& Comp L Rev

J L Relig

JSR

Kansai U Rev L \& Pol

NGTT

PMG

PRC

SACRRF

SALJ

Tex Int'I LJ

UBC Law Rev

Yale J L \& Human
Constitutional Court Review

Parliamentary Portfolio Committee on Cooperative Governance and Traditional Affairs

Columbia Law Review

Commission for the Promotion and Protection of the Rights of Cultural, Religious and Linguistic Communities

Duke Journal of Comparative and International Law

Emory International Law Review

Freedom of Religion South Africa

International Journal of Constitutional Law

International Journal for Religious Freedom

Indiana International and Comparative Law

Review

Journal of Law and Religion

Journal for the Study of Religion

Kansai University Review of Law and

Politics

Nederduitss Gereformeerde Teologiese

Tydskrif

Parliamentary Monitoring Group

Peer-Review Committee

South African Council for the Protection and

Promotion of Religious Rights and Freedoms

South African Law Journal

Texas International Law Journal

University of British Columbia Law Review

Yale Journal of Law and Humanities 